\title{
STUDENT ACADEMIC SUPPORT AS A PREDICTOR OF LIFE SATISFACTION IN UNIVERSITY STUDENTS
}

\section{Ahmet Akın*, Serhat Arslan**, Eyüp Çelik, Çınar Kaya, Nihan Arslan}

*aakin@sakarya.edu.tr;

**serhatarslan@sakarya.edu.tr;

Copyright (C) 2015 Ahmet Akın, Serhat Arslan, Eyüp Çelik, Çınar Kaya, Nihan Arslan. This is an open access article distributed under the Eurasian Academy of Sciences License, which permits unrestricted use, distribution, and reproduction in any medium, provided the original work is properly cited.

\begin{abstract}
The purpose of this study is to examine the relationship between Academic Support and Life Satisfaction. Participants were 458 university students who voluntarily filled out a package of self-report instruments. Student Academic Support Scale and Satisfaction with Life Scale were used as measures. The relationships between student academic support and life satisfaction were examined using correlation analysis and stepwise regression analysis. Life satisfaction was predicted positively by informational support, esteem support, motivational support, and venting support. The results were discussed with respect to the related literature. Academic support has been shown to be an important variable for understanding life satisfaction and well-being.
\end{abstract}

Keywords: academic support, life satisfaction, stepwise regression analysis

\section{INTRODUCTION}

Happiness and subjective well-being has been, and continues to be one of the most important areas for all human beings, regardless of the surrounding time and space. In recent decades, psychologists tended to shift their attention from negative or unpleasant emotional experiences such as anxiety and depression to positive feelings and psychological well-being in general (Ryan \& Deci, 2001). Seligman and Csikszentmihalyi (2000), in their inspiring paper, described this general shift of attention, or movement referred as "positive psychology" and outlined the function and merit of this approach: "A science of positive subjective experience positive individual traits, and positive institution promises to improve quality of life and prevent the pathologies that arise when life is barren and meaningless" (Seligman \& Csikszentmihalyi 2000, p. 5).

The positive experiences that increase the level of subjective well-being are the most important area of studies in positive psychology, because they increase the quality of life (Diener, Lucas, \& Oishi, 2002). Subjective well-being can be described as "a broad category of phenomena that includes people's emotional responses, domain satisfactions, and global judgments of life satisfaction" (Diener, Suh, Lucas, \& Smith, 1999, p. 277). The study of 
happiness had a long history and popularity in philosophical tradition and subjective wellbeing had been studied in psychology extensively (Ryan \& Deci, 2001); and recently the constructs of happiness and life satisfaction have been studied within frameworks of various disciplines (Lim \& Putman, 2010).

Subjective well-being is usually conceptualized as consisting of two distinctive domains. The first one encompasses two clusters of affective and emotional experiences; the presence of positive affect like the pleasant feelings and moods such as joy and pride, and the absence of negative affect which denotes bothersome emotions such as sadness, guilt and anger. (Diener, 2000; Diener, Suh, Lucas, \& Smith, 1999). Life satisfaction is the second domain and encompasses the cognitive experiences that constitute subjective well-being (Andrews \& Withey, 1976). The affective and emotional subdomain of subjective well-being is a pleasurebased general evaluation of one's life, which is primarily grounded on emotions and feelings. The cognitive compound, labeled as life satisfaction, is an information-based evaluation of the worth of one's life and the judgment on the extent to which their life circumstances fulfill their expectations (Pavot \& Diener, 1993). When the person reports being satisfied with life, $\mathrm{s} /$ he is most likely compares his/her perceived life circumstances with a set of self-imposed standards, and is satisfied with the degree that these conditions match those standards (Pavot $\&$ Diener, 1993). Thus, the opinion of satisfaction is contingent upon a comparison of one's circumstances with the desired standards (Diener, Emmons, Larsen, \& Griffin, 1985).

The satisfaction on perceived quality of life is regarded as an important area of study in positive psychology (Keyes, Shmotkin, \& Ryff, 2002); and has received increasing attention as an indicator of optimal functioning (Suldo \& Huebner, 2006). It is obviously one of the main quests of mankind and involves the full range of human functioning. Life satisfaction is also defined as "a global assessment of a person's quality of life according to his/her chosen criteria" (Shin \& Johnson, 1978, p. 478) and one's general evaluation of some aspects of the quality of his/her life, such as family, school, friendships etc. according to his/her thoughts, how far a person reaches the standards he has set (Diener et. al., 1985). In the context of the present study, life satisfaction will be considered as an index of overall functioning and wellbeing of students as an outcome variable.

\section{Student Academic Support}

Peer support which is traditionally defined as academic support from peers usually taking place within the context of courses, one-to-one studying or preparation for exams, has become quite important in the current educational research (Keup \& Mullins, 2010). These skillsbased approaches are quite inadequate to meet the changing requirements of students (ClarkUnite, 2007). However, peer academic support is very important for the students especially in terms of academic skill development, career development, development of efficacy feeling as well as communication skill development and establishing bilateral relationships (Smuts, 1996). Maxvell (2001) in his study, defines academic peer support as "socializing the education". Social support is experienced by the individuals in the social context of people 
who receive help, those who offer help or potential helpers. Peer academic support includes the assistance interaction of students to each other in academic issues (Kenny \& Rice, 1995; Lafreniere \& Ledgerwood, 1997; Shaver \& Buhrmester, 1985).

Lack of social support for the student motivates the student to seek academic support from other students. However, there is little information on the process how academic student support and peer support occur (Chen, 2005; DeBerard, Spielmans, \& Julka, 2004; Tinto, 1997, 2005). Peer academic support includes the solution of academic problems faced by students (e.g., answering of questions about papers, studying together, sharing studying habits, helping with academic difficulties) and academic encouragement (support for reducing exam stress, academically motivating for courses) (Mazer \& Thompson, 2011; Thompson, 2008; Thompson \& Mazer, 2009). Informal peer support in undergraduate level has an important place in terms of the academic support system and academic efficacy levels of students (Braithwaite, Bride, \& Schrodt, 2003; Jones, 2008; Kong, 2009; Mortenson, 2006).

Thompson (2008) stated that methods of communication with each other and academic peer support are quite important for the academic success of students. Academic peer support is effective in the formation of new academic expectations and on the academic support system internalized by the individual (Alfaro, Umana, \& Bamaca, 2006; DeBierard et al., 2004; Kenny \& Rice, 1995; Lafreniere \& Ledgerwood, 1997; Thompson, 2008; Tinto, 2005). In this context, informal academic peer support has a quite important place in the academic success of students (Giddan, 1988; Mpofu, 2003; Penn-Edwards \& Donnison, 2011). Tinto (1997) concluded that social and academic success levels of students are positively related to their academic and social communication methods. Peer academic support is crucial for the education programs achieve their goals. In addition, peer support may have a positive effect on new learning gains of the students.

McKeachie, Pintrich, Lin and Smith (1986) emphasizes that "the answer of the best teaching method is education aims, student, content and teacher. But another answer as an alternative is academic peer support". Many researchers studied the effect of social support on academic success (De Berard, Spielman, \& Julka, 2004; Forman, 1988; Kloomok \& Cosden, 1994; Malecki \& Demaray, 2002). It was concluded that social academic support is related with cognitive, emotional and behavioral factors on the students. In addition, academic peer support has a positive effect on students with learning difficulties and low academic success (Rothman \& Cosden, 1995; Wenz-Gross \& Siperstein, 1997). In studies on university students, it was found that peer support has a positive effect on academic success (Elliott, 2007; Mazer \& Thompson, 2011; Thompson, 2008; Thompson \& Mazer, 2009). These supportive interactions among university students have a developmental effect on social support and peer relations. Thompson (2008) examined the academic support process thoroughly in terms of students and presented the factors which affect academic support processes of university students. 


\section{Research Focus and Problems of Research}

Few studies have connected life satisfaction with school characteristics (Valois, Zullig, Huebner, \& Drane, 2009) and, to our knowledge, no research has been conducted investigating life satisfaction's relationship to academic support. Thus, the aim of the present study is to examine the relationship between student academic support and life satisfaction. In present research the life satisfaction has been considered as an outcome and student academic support as the predictor. It is hypothesized that student academic support would be associated positively with life satisfaction based on the studies on student academic support (Alfaro, Umana, \& Bamaca, 2006; Chen, 2005; DeBerard, Spielmans, \& Julka, 2004; Kenny \& Rice, 1995; Lafreniere \& Ledgerwood, 1997; Maxvell, 2001; Mazer \& Thompson, 2011; Thompson, 2008; Thompson \& Mazer, 2009; Thompson, 2008; Tinto, 2005) and life satisfaction (Diener, Lucas, \& Oishi, 2002; Diener, Suh, Lucas, \& Smith, 1999; Keyes, Shmotkin, \& Ryff, 2002; Lim \& Putman, 2010; Pavot \& Diener, 1993).

\section{METHOD}

Life satisfaction as a global indicator of well-being and happiness, is a central theme in healthy functioning of individuals. Academic support, on the other hand is a special form of social support usually taking place in educational institutions. In the present study, possible predictive relationship between the constructs of life satisfaction and academic support has been investigated in a quantitative correlational research design.

\section{Participants}

Participants were 458 (245 (54\%) were female and 213 (46\%) were male) university students from a medium size, public university. This university is located in the city of Sakarya and attracts students mainly from cities across the Turkey. Of the participants, 131 (29\%) were first-year students, 119 (26\%) were second-year students, 109 (24\%) were third-year students, and $99(21 \%)$ were fourth-year students. Their ages ranged from 18 to 30years old $(\mathrm{M}=$ 21.51, $\mathrm{SD}=2.43$ ) and their GPA scores ranged from 1.86 to 3.70 .

\section{Instruments and Procedures}

Student Academic Support Scale (SASS). SASS developed by Mazer and Thompson (2011) consists of 15 item including sub-dimensions of information support, respect support, motivation support and relieving support has a 5-point Likert type grading (1 Never - 5 Always). A development study of the original scale was conducted on 253 individuals. Fit index values of four-dimensional model in confirmatory factor analysis applied to structure validity of the scale was found as follows: $\chi 2=83.17, \mathrm{p}<.01$, RMSEA $=.067$, NNFI $=.98$, $\mathrm{CFI}=.99, \mathrm{SRMR}=.03$. The internal consistency reliability coefficient is .94 for information support sub-dimension, .78 for respect support sub-dimension, .81 for motivation support subdimension and .84 for relieving support sub-dimension. Under criterion-related validity, a 
positive relationship was found with "Inventory of Social Support Behaviors" $(\mathrm{r}=.75, \mathrm{p}<.01)$ and "Perceived Social Support Scale" ( $r=.44, \mathrm{p}<.01)$.

The Satisfaction with Life Scale (SWLS). The SWLS developed by Diener, Emmons, Larsen, and Griffin (1985) consists of five items (e.g., In most ways my life is close to my ideal) and each item was presented at a 7-point Likert type scale ranging from $1=$ strongly disagree to $7=$ strongly agree. Turkish adaptation of this scale had been done by Durak, Senol-Durak, and Gencoz (2010). They found that internal consistency was .81 for Turkish university students. A sum of all scores yields a total score that ranges from 5 to 35; a higher score indicates a higher life satisfaction level.

The convenience sampling technique was used in the selection of participants. Convenience sampling is a non-probability sampling technique in which participants are selected because of their convenient accessibility and proximity to the researcher (Bryman, 2004). For this reason, the results of this study did not make inferences from population, which let to decrease external validity. Participants voluntarily participate and are free to fill out questionnaires without pressure. Completion of the questionnaires was anonymous and there was a guarantee of confidentiality. The instruments were administered to the students in groups in the classrooms. The measures were counterbalanced in administration. Prior to administration of measures, all participants were told about the purposes of the study.

Students voluntarily participated in research, completion of the scales was anonymous and there was a guarantee of confidentiality. The scales were administered to the students in groups in the classrooms. Prior to administration of scales, all participants were told about the purposes of the study. In this research, Pearson correlation coefficient and multiple regression analysis were utilized to determine the relationships between dimensions of test anxiety and life satisfaction.

\section{Data Analysis}

Four hundred and seventy-eight students participated in the study. However, students were excluded from the study because 10 of them did not respond to the instruments as required and 10 were found to produce extreme scores. Therefore, the data obtained from 458 students were statistically analyzed. In this research, Pearson correlation coefficient and multiple regression analysis were utilized to determine the relationships between student academic support and life satisfaction. These analyses were carried out via SPSS 11.5. 


\section{RESULTS}

\section{Descriptive Data and Inter-correlations}

Table 1 shows the means, standard deviations, inter-correlations, and internal consistency coefficients of the variables used. Preliminary correlation analysis showed that informational support $(r=.60)$, esteem support $(r=.53)$, motivational support $(r=.50)$, and venting support $(r=.47)$ related positively associated with life satisfaction. Independent sample $t$ tests revealed that there were not any statistically significant gender differences in students academic support and life satisfaction.

Table 1 Descriptive Statistics and Inter-correlations of the Variables

\begin{tabular}{llllll}
\hline Variables & 1 & 2 & 3 & 4 & 5 \\
\hline $1 . \quad$ Informational Support & - & & & & \\
2. Esteem Support & $.57^{* *}$ & - & & & \\
3. Motivational Support & $.56^{* *}$ & $.75^{* *}$ & - & & \\
4. Venting Support & $.60^{* *}$ & $.55^{* *}$ & $.60^{* *}$ & - & \\
5. Life satisfaction & $.60^{* *}$ & $.53^{* *}$ & $.50^{* *}$ & $.47^{* *}$ & - \\
Mean & 28.75 & 12.79 & 12.63 & 8.64 & 29.49 \\
Standard deviation & 6.2 & 2.41 & 2.64 & 1.80 & 5.09 \\
\hline$* * p<.01$ & & & & &
\end{tabular}

$* * p<.01$

\section{Multiple Regression Analysis}

Before applying regression, assumptions of multiple regression were checked. The data were examined for normality by the Kolmogorov-Smirnov test. The Kolmogorov-Smirnov test indicated normality of distributions of test scores for all tests in the current study. Outliers are cases that have data values that are very different from the data values for the majority of cases in the data set. Outliers were investigated using Mahalanobis distance. A case is outlier if the probability associated with its $\mathrm{D}^{2}$ is .001 or less (Tabachnick \& Fidell, 2001). Based on this criterion, five data were labeled as outliers and they were deleted. Multi-collinearity was checked by the variance inflation factors (VIF). All the VIF values were less than 10 (Tabachnick \& Fidell, 2001), which indicated that there was no multi-collinearity.

Stepwise multiple regression analysis has applied to determine which dimensions of student academic support were the best predictors of life satisfaction. Table 2 showed the results of multiple regression analysis where the independent variables were the dimensions of between student academic support and the dependent variable was life satisfaction. 
Table 2 Summary of Stepwise Multiple Regression Analysis for Variable Predicting Life Satisfaction

\begin{tabular}{llllllllll}
\hline Variables & $B$ & $S E_{B}$ & $B$ & $t$ & $p$ & $R$ & $R^{2}$ & $F$ & $p$ \\
\hline Step 1 & & & & & & & & & \\
Informational support & .495 & .029 & .606 & 16.891 & .00 & .606 & .367 & 285.30 & .00 \\
Step 2 & & & & & & & & & \\
Informational support & .367 & .034 & .449 & 10.783 & .00 & & & & \\
Esteem support & .590 & .088 & .278 & 6.676 & .00 & .648 & .420 & 44.571 & .00 \\
Step 3 & & & & & & & & & \\
Informational support & .352 & .035 & .431 & 10.053 & .00 & & & & \\
Esteem support & .466 & .115 & .219 & 4.047 & .00 & .650 & .423 & 2.850 & .09 \\
Motivational support & .176 & .104 & .091 & 1.688 & .09 & & & & \\
Step 4 & & & & & & & & & \\
Informational support & .328 & .038 & .402 & 8.691 & .00 & & & & \\
Esteem support & .450 & .115 & .212 & 3.909 & .00 & & & & \\
Motivational support & .128 & .108 & .066 & 1.188 & .23 & .653 & .426 & 2.826 & .09 \\
Venting support & .223 & .133 & .079 & 1.681 & .09 & & & & \\
\hline * $p<.01$ & & & & & & & & &
\end{tabular}

Informational support entered the equation first, accounting for $37 \%$ of the variance in predicting life satisfaction. Esteem support entered in the second step accounting for an additional 5\% variance. The last regression models, informational support, esteem support, motivational support and venting support as predictors of life satisfaction and accounted for $43 \%$ of the variance in life satisfaction. The standardized beta coefficients indicated the relative influence of the variables in last model with informational support $(\beta=.40, \mathrm{p}<.01)$, esteem support $(\beta=.21, \mathrm{p}<.05)$, motivational support $(\beta=.07, \mathrm{p}<.05)$ and venting support $(\beta=$ $.08, \mathrm{p}<.05)$ all significantly influencing life satisfaction and informational support were the strongest predictor of life satisfaction.

\section{DISCUSSION}

The main aim of the present study was to examine the relationships between academic support and students' life satisfaction and whether academic support predicted students' life satisfaction levels. The results clearly supported the hypotheses of the study. Preliminary correlation analyses showed that informational support, esteem support, motivational support, and venting support were positively associated with life satisfaction. As a result of stepwise regression analysis, informational support and esteem support predicted life satisfaction significantly, whereas motivational support and venting support did not predict life satisfaction significantly. The present study findings are discussed in view of related variables with academic support.

When comparing the predictive values of life satisfaction included in stepwise regression analysis the most predictive subdomain is informational support. This result showed that the 
more informational support and esteem support level increased, the more life satisfaction level increased. Examining the literature, it is seen that the present study's findings are in accordance with previous research findings (Danielsen, 2009; Diener \& Fujita, 1995; Gilman, Huebner, \& Laughlin, 2000; Hamre \& Pianta, 2006; Huebner, Suldo, Smith, \& McKnight, 2004; Natvig, Albrektsen, \& Qvarnstrøm, 2003; Reddy, Rhodes, \& Mulhall, 2003; Suldo, Riley, \& Shaffer, 2006).

Student academic support includes peer support (Braithwaite, Bride, \& Schrodt, 2003; Jones, 2008; Keup \& Mullins, 2010; Kong, 2009; Mazer \& Thompson, 2011; Mortenson, 2006; Thompson, 2008; Thompson \& Mazer, 2009), social support (Kenny \& Rice, 1995; Lafreniere \& Ledgerwood, 1997; Shaver \& Buhrmester, 1985), and social academic support (Rothman \& Cosden, 1995; Wenz-Gross \& Siperstein, 1997) such as teacher support, classmate support, and parental support. Danielsen (2009) stated that students' life satisfaction judgments are likely to be influenced by students' different social (e.g., friend, family individual, teacher) and individual resources.

In the literature, there is no study examining the relationships between student academic support and life satisfaction, but researchers examined the relations between school-related social support and life satisfaction (Danielsen, 2009; Oberle, Schonert-Reichl, \& Zumbo, 2011; Flaspohler, Elfstrom, Vanderzee, Sink, Birchmeier, 2009; Siddall, Huebner, Jiang, 2013; Marion, Laursen, Zettergren, \& Bergman, 2013). Also school is regarded as a major domain of students' life satisfaction (Gilman, Huebner, \& Laughlin, 2000; Suldo, Riley, \& Shaffer, 2006). Furthermore, a study result has shown that increased feelings of school alienation were related to a decrease in happiness level (Natvig, Albrektsen, \& Qvarnstrøm, 2003). School alienation indicates lower perceived support such as receiving from academic, peer, teacher, family, and staff support. These support resources are important to providing informational support which increases students' life satisfaction. Also students' life satisfaction can increase with esteem support provided to student by family members, friends, and teachers.

\section{CONCLUSIONS}

The present study findings are encouraging for continued investigation of how academic support relates to student life satisfaction. Despite these promising results, there are important limitations in our study. We relied solely on the self-reports of our participants. Therefore, future research should collect the perspectives of others, including teachers, staff, peers, and families to further our understanding the relationship between academic support and life satisfaction. Social support from peers, families, significant others, and teachers may serve to buffer the impact of decrease in academic achievement and performance, and may increase student life satisfaction. Future research should focus on various aspects of social support which may affect life satisfaction positively.

\section{Acknowledgements}

Authors of the present manuscript do not have any conflicts of interest. 


\section{REFERENCES}

- Akın, A. (2006). 2X2 achievement goal orientations scale. Sakarya University Journal of Education, 12, 1-13.

- Akın, A. (2008a). Self-compassion and achievement goals: A structural equation modeling approach. Eurasian Journal of Educational Research, 31(8), 1-15.

- Alfaro, C. A. , Umana-Talor, J. A., \& Bamaca, Y. M. (2006). The influence of academic support on latino adolescents' academic motivation. Family Relations, 55, 279-291.

- Andrews, F. M., \& Withey, S. B. (1976). Social indicators of well-being: Americans' perceptions of life quality. New York: Plenum.

- Braithwaite, D. O., McBride, M. C., \& Schrodt, P. (2003). Parent teams and the everyday interactions of co-parenting in stepfamilies. Communication Reports, 16(2), 93-111.

- Bronfenbrenner, U. (1977). Toward an experimental ecology of human development. American Psychologist, 32, 513-31.

- Chang, L., McBride-Chang, C., Stewart, S. M., \& Au, E. (2003). Life satisfaction, self concept, and family relations in Chinese adolescents and children. International Journal of Behavioral Development, 27(2), 182-189.

- Chen, J. L. J. (2005). Relation of academic support from parents, teachers, and peers to Hong Kong adolescents' academic achievement: The mediating role of academic engagement. Genetic, Social, and General Psychology Monographs, 131(2), 77-127.

- Chow, H. P. (2005). Life satisfaction among university students in a Canadian Prairie city: A multivariate analysis. Social Indicators Research, 70, 139-150.

- Clark-Unite, C. (2007). A critique of supplemental instruction programme. A case study at the University of Port Elizabeth (1993-2005). Unpublished thesis, University of Port Elizabeth.

- Danielson, A. G., Samdal, O., Hetland, J., \& Wold, B. (2009). School-related social support and students' perceived life satisfaction. Journal of Educational Research, 102, 303-318.

- De Berard, M. S., Spielmans, G. I., \& Julka, D. C. (2004). Predictors of academic achievement and retention among college freshmen: A longitudinal study. College Student Journal, 38(1), 66-80.

- Deniz, M. E., \& Yilmaz, E. (2004). The relationship between emotional intelligence and life satisfaction of university students. Paper presented at the XIII National Educational Sciences Congress, 6-9 July, İnönü University, Malatya, Turkey.

- Diener, E. (2000). Subjective well-being. The science of happiness and a proposal for a national index. American Psychologist, 55, 34-43.

- Diener, E., \& Fujita, F. (1995). Resources, personal strivings, and subjective wellbeing: A nomothetic and idiographic approach. Journal of Personality and Social Psychology, 68, 926-935.

- Diener, E., Emmons, R., Larsen, J., \& Griffin, S. (1985). The Satisfaction with Life Scale. Journal of Personality Assessment, 49(1), 71-75.

- Diener, E., Suh, E., Lucas, R. E., \& Smith, H. L. (1999). Subjective well-being: Three decades of progress. Psychological Bulletin, 125, 276-302.

- Flaspohler, P. D., Elfstrom, J. L., Vanderzee, K. L., Sink, H. E., \& Birchmeier, Z. (2009). Stand by me: The effects of peer and teacher support in mitigating the impact of bullying on quality of life. Psychology in the Schools, 46(7), 636-649. 
- Forman, E. (1988). The effects of social support and school placement on the selfconcept of LD students. Learning Disability Quarterly, 11(2), 115-124.

- Giddan, N. S. (1988). Community and social support for college students. Springfield, IL: C. C.Thomas.

- Gilman, R., Huebner, E. S., \& Laughlin, J. E. (2000). A first study of the Multidimensional Students' Life Satisfaction Scale with adolescents. Social Indicators Research, 52(2), 135-160.

- Hamre, B. K., \& Pianta, R. C. (2006). Student-teacher relationships. In G. G. Bear \& K. M. Minke (Eds.), Children's needs: Part III. Development, prevention, and intervention (pp. 59-72). Bethesda, MD: National Association of School Psychologists.

- Henry, C. S. (1994). Family system characteristics, parental behaviors, and adolescent family life satisfaction. Family Relations, 43, 447-455.

- House, D. J. (1992). The relationship between academic self-concept and school withdrawal. The Journal of Social Psychology, 133, 125-127.

- Huebner, E. S., Suldo, S. M., Smith, L. C., \& McKnight, C. G. (2004). Life satisfaction in children and youth: Empirical foundations and implications for school psychologists. Psychology in the Schools, 41(1), 81-93.

- Jones, A. C. (2008). The effects of out-of-class support on student satisfaction and motivation to learn. Communication Education, 57(3), 373-388.

- Kenny, M. E., \& .Rice, K.G. (1995). Attachment to parents and adjustments in late adolescent college students: Current status, applications, and future considerations. The Counseling Psychologist, 23(3), 433-456.

- Keup, J. R., \& E. Mullins (2010). Findings from National survey of peer leadership experinces and outcomes. Concurent session presented at the 29th Annual Conference on The First-Year Experince, Denver, February.

- Keyes, C. L., Shmotkin, D., \& Ryff, C. (2002). Optimizing well-being: The empirical encounter of two traditions. Journal of Personality and Social Psychology, 82, 10071022 .

- Kloomok, S., \& Cosden, M. (1994). Self-concept in children with learning disabilities: The relationship between global self-concept, academic "discounting," nonacademic self-concept, and perceived social support. Learning Disability Quarterly, 17(2), 140153.

- Kong, W. (2009). Student feedback on tutor and academic support of Wawasan Open University a four-semester study. The Quarterly Review of Distance Education, 10(4), 363-379.

- Lafreniere, K. D., \& Ledgerwood, D. M. (1997). Influences of leaving home, perceived family support, and gender of the transition to university. Guidance \& Counseling, 12(4), 14-18.

- Lim, C., \& Putman, R. (2010). Religion, social networks and life satisfaction. American Sociological Review, 756, 914-933.

- Malecki, K. C., \& Demaray, K. M. (2002). Measuring perceived social support: development of the child and adolescent social support scale (CASSS). Psychology in the Schools, 39(1), 1-18.

- Marion, D., Laursen, B., Zettergren, P., \& Bergman, L. R. (2013). Predicting life satisfaction during middle adulthood from peer relationships during mid-adolescence. Journal of Youth Adolescence, 42, 1299-1307. DOI 10.1007/s10964-013-9969-6. 
- Maxwell, M. (2001). Peer tutoring: An overview; history and research on program effectiveness. Journal of the National Tutoring Association, 1(1), 8-18.

- Mazer, J. P., \& Thompson, B. (2011). The validity of the student academic support scale: Associations with social support and relational closeness. Communication Reports, 24(2), 74-85.

- McKeachie, W. J., Pintrich, P. R., Lin, Y., \& Smith, D. A. F (1986). Teaching and learning in the college classroom: A review of literature. Michigan: The University of Michigan.

- Mortenson, S. T. (2006). Cultural differences and similarities in seeking social support as a response to academic failure: A comparison of American and Chinese college students. Communication Education, 55(2), 127-146.

- Mpofu, E. (2003). Enhancing social acceptance of early adolescents with physical disabilities: Effects of role salience, peer interaction, and academic support interventions. International Journal of Disability, Development and Education, 50(4), 435-454.

- Natvig, G. K., Albrektsen, G., \& Qvarnstrøm, U. (2003). Associations between psychosocial factors and happiness among school adolescents. International Journal of Nursing Practice, 9, 166-175.

- Oberle, E., Schonert-Reichl, K. A., \& Zumbo, B. D. (2011). Life satisfaction in early adolescence: Personal, neighborhood, school, family, and peer influences. Journal of Youth Adolescence, 40, 889-901.

- Penn-Edwards, S., \& Donnison, S. (2011). Engaging with higher education academic support: A first year student teacher transition model. European Journal of Education, 46(4), 566-580.

- Powers, L. C. (2008). Academic achievement and social involvement as predictors of life satisfaction among college students. Psi Chi Journal of Undergraduate Research, 13(3), 128-135.

- Reddy, R., Rhodes, J. E., \& Mulhall, P. (2003). The influence of teacher support on student adjustment in the middle school years: A latent growth curve study. Development and Psychopathology, 15(1), 119-138.

- Rothman, H. R., \& Cosden, M. (1995). The relationship between self-perception of a learning disability and achievement, self-concept and social support. Learning Disability Quarterly, 18(3), 203-212.

- Rueger, S. Y., Malecki, C.K., \& Demaray, M. K. (2010). Relationship between multiple sourcesof perceived social support and psychological and academic adjustment in early adolescence: Comparisons across gender. Journal of Youth and Adolescence, 39, $47-61$.

- Ryan, R. M., \& Deci, E. L. (2001). On happiness and human potentials: A review of research on hedonic and eudaimonic well-being. Annual Review of Psychology, 52, 141-166.

- Seligman, M. E. P., \& Csikszentmihalyi, M. (2000). Positive psychology: An introduction. American Psychologist, 55(1), 5-14.

- Shaver, P., Furman, W., \& Buhrmester, D. (1985). Transition to college: Network changes, social skills, and loneliness. In S. W. Duck \& D. Perlman (Eds.), Understanding personal relationships: An interdisciplinary approach Beverly Hills, CA: Sage.

- Shin, D. C., \& Johnson, D. M. (1978). Avowed happiness as an overall assessment of the quality of life. Social Indicators Research, 5(1-4), 475-492. 
- Siddall, J., Huebner, E. S., \& Jiang, X. (2013). A prospective study of differential sources of school-related social support and adolescent global life satisfaction. American Journal of Orthopsychiatry, 83(1), 107-114.

- Smuts, K. B. (1996). The role of student leaders in supplemental instruction. South African Journal of Higher Education, 16(3), 225-231.

- Stewart, T., \& Suldo, S. (2011). Relationships between social support sources and early adolescents' mental health: The moderating effect of student achievement level. Psychology in the Schools, 48(10), 1016-1033.

- Suldo, S. M., \& Huebner, E. S. (2006). Is extremely high life satisfaction during adolescence advantageous?. Social Indicators Research, 78, 179-203.

- Suldo, S. M., \& Huebner, E. S. (2006). Is extremely high life satisfaction during adolescence advantageous?. Social Indicators Research, 78, 179-203.

- Suldo, S. M., Huebner, E. S., Friedrich, A. A., \& Gilman, R. (2009). Life satisfaction. In R. Gilman, E. S. Huebner, \& M. Furlong (Eds.), Handbook of positive psychology in the schools (pp. $27-35$ ). New York: Routledge.

- Suldo, S. M., Riley, K. N., \& Shaffer, E. J. (2006). Academic correlates of children and adolescents' life satisfaction. School Psychology International, 27, 567-582.

- Suldo, S., Riley, N. K., \& Shaffer, J. E. (2006). Academic Correlates of Children and Adolescents' Life Satisfaction. School Psychology International, 27(5), 567-582.

- Thompson, B. (2008). How college freshmen communicate student academic support: A grounded theory study. Communication Education, 57(1), 123-144.

- Thompson, B., \& Mazer, J. P. (2009). College student ratings of student academic support: Frequency, importance, and modes of communication. Communication Education, 58(3), 433-458.

- Tinto, V. (1997). Classrooms as communities: Exploring the educational character of student persistence. Journal of Higher Education, 68(6), 599-623.

- Tinto, V. (2005). Reflections on retention and persistence: Institutional actions on behalf of student persistence. Studies in Learning, Evaluation, Innovation, and Development, 2(1), 89-97.

- Valois, R. F., Zullig, K. J., Huebner, E. S., \& Drane, J. W. (2009). Youth developmental assets and perceived life satisfaction. Is there a rellationship? Applied Research on Quality of Life, 4, 315-331.

- Wenz-Gross, M., \& Siperstein, G. N. (1997). Importance of social support in the adjustment of children with learning problems. Exceptional Children, 63(2), 183-193.

- Yalçın, İ. (2011). Social support and optimism as predictors of life satisfaction of college students. International Journal for the Advancement of Counselling, 33, 7987. 